\title{
UNEMPLOYMENT CRISIS AMONG FRESH GRADUATES
}

\author{
Dr. Nor Azilah Husin \\ Associate Professor and Deputy Dean \\ Faculty of Business and Accountancy \\ Universiti Selangor \\ 40000 Shah Alam, Selangor, Malaysia \\ E-mail: nor_azilah@unisel.edu.my \\ (iDhttps://orcid.org/0000-0002-1513-8550 \\ Dr. Salina Rasli \\ Senior Lecturer \\ Faculty of Business and Accountancy \\ Universiti Selangor, 40000 Shah Alam, Selangor, Malaysia \\ E-mail: rsalina@unisel.edu.my \\ Dhttps://orcid.org/0000-0003-2086-380X \\ Murugan Shri Ganesh Kumar \\ Faculty of Business and Accountancy \\ Universiti Selangor, 40000 Shah Alam, Selangor, Malaysia \\ E-mail: lengchaiimurugan@gmail.com \\ (iDhttps://orcid.org/0000-0002-9679-9544 \\ Ganeswary Suppiah \\ Department of Administrative Management and Human Resource \\ Faculty of Business and Accountancy \\ Universiti Selangor, 40000 Shah Alam, Selangor, Malaysia \\ E-mail: ganeswarysuppiah06@gmail.com \\ (i) https://orcid.org/0000-0002-4151-4927
}

Received: October 01, $2021 \quad$ Accepted: November 04, $2021 \quad$ Online Published: November 28, 2021

DOI: 10.46281/aijssr.v10i1.1461

URL: https://doi.org/10.46281/aijssr.v10i1.1461

\begin{abstract}
This paper attempts to explore the topic of the unemployment crisis among fresh graduates. The two main objectives of the study are to examine the influence factors of the unemployment crisis among fresh graduates in Malaysia, and the primary determinant of the unemployment has culminated in many policy implications for higher education. The unemployment rate among fresh graduates increased to $25 \%$ in 2020 than the year before, jumping from 13.8\%. The null hypothesis is that employer preference, candidate attributes, and economic instability have no significant effect on the unemployment crisis. The information for the paper typically originates from a
\end{abstract}


questionnaire survey method, with one hundred and thirty fresh graduates' participation in this study. The statistical approach is required to analyze numerical data using SPSS applications. Descriptive analyses such as frequency and simple percentages on demographic characteristics were used to analyze data. Inferential statistics such as linear bivariate correlation was used to test the formulated hypothesis. The finding demonstrated a significant association between employer preference, candidate attributes, and economic instability with the unemployment crisis. This finding would shed light on more preparation for fresh graduates' employability who preserve searching for a job by the education ministry. Hopefully, a revision in the academic higher education curriculum is considered to meet the job market's and stakeholders' needs for better graduate employability.

Keywords: Unemployment Crisis, Employer Preference, Candidate Attributes, Economic Instability.

JEL Classification Codes: F62, F66, J64, M54.

\section{INTRODUCTION}

Globalization, disruptive technologies, and digital transformation changing lifestyle and consumer tastes provide jobs and careers with extensive opportunities and risks (Seng, 2018). Moreover, unemployment among graduates in Malaysia seems to upsurge year after year with the challenging economic environment. A report by the Ministry of Education's Graduate Tracer Study (SKPG) for 2018 estimated 341,311 graduated from 702 institutions of higher learning and General Skills Training Institutions (ILKA). This information consists of 20 public universities, 267 private institutions of higher education, 33 polytechnics, 89 community colleges, 82 vocational colleges, 33 institutes of the Ministry of Human Resources, 19 institutes of the Ministry of Youth and Sports, 11 institutes of the Ministry of Agriculture and Agro-Based Industry, 146 institutes of the Ministry of Rural Development and two other institutions of higher learning. Within six months of graduating, the graduate employability rate for 2018 was 80.2 percent, with 58.6 percent attaining jobs, including in entrepreneurial ship. Another 15.7 percent furthered their education; 1.3 percent underwent training for skill improvement, and 4.6 percent were waiting for a job placement which only 19.8 percent contributes to unemployment.

In 2020, the unemployment rate for new graduates rose to $25 \%$, up from 13.8 percent the year before, bringing the total number of recent unemployed graduates to 116,161 (Consultant, 2021). Malaysia's unemployment rate rose to 4.5 percent in 2020, the highest level since 1993, when it was 4.1 percent, according to the Malaysian Department of Statistics (DoSM, 2021). According to Datuk Seri Dr Mohd Uzir Mahidin, chief statistician, unemployment grew to 772,900 people at a rate of 4.8 percent in December 2020, while the number of working people increased by 0.1 percent month-on-month, or 19,300 people, to 15.22 million people (Bernama, February 8, 2021). He said the country experienced a slower labour demand in 2020 due to the adverse impact of the Covid-19 pandemic. And the health crisis had had a considerable effect on the labour force, which led the unemployment rate to reach above four percent against an average of three percent recorded in the pre-crisis period. Meanwhile, Mohamad (2020) restated that there were 5.8 out of 10 unemployed people below age 24, and the total unemployment rate was 56.9 percent of unemployed female graduates and 43.1 of the male graduates in 2018. The highest unemployed fresh graduates are from the social sciences, and business \& law fields with 35.0 percent and 2.5 percent were the lowest of unemployed fresh graduates from agriculture and veterinary. 
Unemployment has emerged as a burning issue in the current economic scenario, both in developing and developed countries. This common issue is, however, affected by different factors in every country. As described by the International Labour Organisation, unemployment occurs when people are without jobs and have been actively looking for work over the past four weeks (Morozova, 2017). While unemployment is a natural phenomenon, when the length of unemployment for any individual is too long, this phenomenon becomes a problem. Tengku Kamarul Bahrim, Hassan Azahari, Zulkarnal, Sallehhudin, and Mohd Yusop (2019) detected several consequences of unemployment indirectly among the graduates. Firstly, unemployment could lead to criminal activities as unemployed people have lost their support for living. Apart from that, mental health can also be affected due to stress and pressures. Lastly, unemployment could also be affected by the marriage or family of the unemployed person as money and income are very important.

Moreover, students at the college usually attend their institution and graduate within a specific time. Although graduates want to have moderate incomes based on investment returns, they often face unemployment following graduation. Unemployment can happen in the short or long term. Natural processes that someone graduates move from one job to another or moving from school to the job market is only valid unemployment in the short time. Meanwhile, new graduates entered the workforce and were not gainfully employed for several reasons are longterm unemployment (Rajoo, 2016). This scenario reflects how this situation generates competition between graduates who have long graduated but are not employed and have just graduated and looked for a job.

Verhaest, Bogaert, Dereymaeker, Mestdagh, and Baert (2018) pronounce the unemployment crisis issues among fresh graduates in how employers are stereotyped as more likely to prioritize the candidates who have working experience against highly qualified fresh graduates but for experience only in theory. Hence, this attitude of employers who prefer this experience had caused many unemployed graduates. Thus, the main objective of this study is to investigate the determinants of the unemployment crisis so that it will help fresh graduates find a fit job and help them enhance some skills required by the job market. Hopefully, the organization or government should take necessary actions to encourage the unemployed to improve the employment opportunities in reducing the unemployment rate.

\section{Unemployment Crisis}

\section{LITERATURE REVIEW}

Almost no consideration has been paid to real the meaning of unemployment. However, it creates the impression that most occupation-centered grant compares unemployment to the absence of paid work (O'Halloran et al., 2018). Unemployment is described as people who have no job, are actively searching for work, and currently available for work. People who were temporarily laid off and waited to be transferred to the position are also counted in unemployment-high unemployment results in resource wastage and economic misery. Unemployment is one of the nation's key issues, whether it is a developed and prosperous country or a poor one. However, while unemployment is a natural occurrence, and this occurrence becomes an issue when the period of unemployment is too long for anyone, particularly for fresh graduates. Hossain (2018) argues that if an unemployment issue is not resolved, the contribution to the unemployed graduates, nation, society, and even the country will undoubtedly grow. Unemployment is a key concern and represents one nation's below-utilization of energy. All people who are jobless, open to working, and looking for jobs are unemployed. Hwang (2017) postulated that college students 
usually attend their institution and graduate within a specific time frame. While graduates want to have sufficient incomes based on investment return, they sometimes face unemployment after graduation. Unemployment is detrimental to the individual because it leads to financial deficits based on college debts and educational expenses. If graduates do not have the essential skills to meet employers' needs, then the unemployment rate will increase unnecessarily.

Many people were mourning and traumatised due to the beginning of this era of global unemployment, which is related causally and temporally to a severe loss of life and disease. The first step in creating a strategic plan for unemployment in the COVID-19 period is defining the essence of this phase of failure in so many vital areas. As a result, a significant research issue is how different this unemployment crisis is from past periods of unemployment related to economic fluctuations. According to a considerable body of research, youth unemployment is linked to poor physical and mental health, as well as increased smoking and alcohol intake (Thern, 2017). Furthermore, adolescence continues to be a fragile time of life, as recent research has shown that the effects of youth unemployment on mental health persist into adulthood, regardless of subsequent unemployment experiences.

\section{Employer Preferences}

Employers prefer the required knowledge, skills, and attitudes (KSA) from fresh graduates (Belwal, Priyadarshi, \& Al Fazari, 2017). Their preference for KSA demands the quality of education for entering a dwindling job market. Employers are always hiring unemployed graduates based on their CGPA marks, gender, age, culture, and race (Amen, 2014). They have some perceptions about the unemployed graduates as some of them cannot be the best performer to their organization. They feared hiring them for the previous issues that happened with fresh graduates. And employers have more own rules to engage their employees (Mulders, 2019). For example, the manager hired the best Employer, such as a topper at university with a high CGPA. Attitudes of employers who prefer this experience caused many unemployed graduates.

Moreover, some employers hire an employee who discriminates of age. Most of them have the perception that young employees can work fast, more energetic, and complete the task on time. The employers are quickly judging the fresh graduates' attitudes from their first view at resume and interview. Rajoo (2016) reiterated that a self-confident attitude would gain graduates' knowledge and skills in a work area. Through the experience gained, graduates need to think about solving a problem efficiently and increase productivity. Employers' market demand expects job candidates' eager graduates and highly motivated, confident, try to develop their careers and improve productivity. When recruiting a new employee, many employers have a clear preference for younger employees, while preferences for older workers are uncommon (Mulders, 2019). Employer age of retirement patterns is linked to a reduced selection for younger jobs across the board in all job decisions. Employers who are more optimistic about older workers' soft skills (such as consistency and interpersonal skills) and not their strong qualities (such as physical ability and desire to learn) score more senior employees more favourably for recruiting and training full-time jobs. Social norms and stereotypes have been shown in the literature to harm older workers' job prospects and behaviour. Social expectations on when to retire can affect older workers' longevity and organisations' support for working past the traditional retirement age (Mulders, 2019). Mncayi, (2016) study stated that unemployment happens because employers are more willing to hire workers with experience. Fresh graduates with no experience are stay behind and cause unemployed. Based on this argument, the researchers formulated the following hypothesis:

\section{$H_{1}$ : There is a significant influence of employer preference towards unemployment crisis.}




\section{Candidate Attributes}

Unemployment is dreadful for young individuals and communities as a whole; nevertheless, the adverse effects of unemployment rates are generally correlated with longer-term unemployment rather than unemployment itself (O'Higgins, 2016). Young people have felt the most damaging effects of the recession in this region. The rate of long-term unemployment among the young rose by more than a third during the recession. Furthermore, this is not the only recent negative development in young people's labour market experiences with long-term implications. In recent years, there has been a growing awareness that joblessness, as it is now commonly referred to, is a cause for concern (Verd, 2019). Similarly, the rise in temporary and part-time jobs among young people and the long-term effects of these contractual forms are becoming a significant concern.

The unemployment rate among fresh graduates is increasing from time to time. This problem happens because of many factors, and we are not going to blame the company only, but the candidates should also be blamed. It is why because the author fined the reason why unemployment among fresh graduates happens. Candidates themselves are one reason why unemployment among fresh graduates happens (Jayasingam, 2018). Some candidates being picky in choosing their job, especially if they have graduated with a bachelor or master. They tend to look for a high-position job. But to get the highest position, candidates need to have a working experience, but most fresh graduates do not have it.

Additionally, employers prefer skills and experience, capabilities, personal qualities, and skills beyond educational background and are in line with current labour market demands (Suppramaniam, 2019). These graduates are too demanding; they tend to reject all the low positions and willing to be unemployed people until they get what they want. This gap between skills needed in the workforce and individuals' skills addresses doubts regarding societies' ability to capitalise on employees (Pheko \& Molefhe, 2017). Therefore, the researchers designed the following hypothesis:

\section{$\mathrm{H}_{2}:$ There is a significant influence of the candidate attribute on the unemployment crisis.}

\section{Economic Instability}

During economic recessions, getting employed will be challenging where human skills will compete with the new technologies. Most employers chose machines as their workers to decrease inflation to serve their workers (Tengku Kamarul Bahrim, 2019). He agrees that most companies, especially the factories, would instead choose machines compared to the human workforce where they could decrease the payment of workers and increase the volume of productions. From an economic perspective, being over-educated in the labor market exemplifies graduates who exceed the socially optimal level of education. According to the law of labour supply and demand, they should get a job regardless of their educational attainment. It is at this point that conflicts occur. While the group wants to earn more returns to balance educational costs, ordinary workplaces that require lower academic requirements do not provide sufficient salaries or benefits to make up for the opportunity cost of education (Hwang, 2017).

When the economy's regular activity is interrupted, economic uncertainty exists. Instability erodes interest, resulting in lower investment, lower consumption, lower productivity, and higher unemployment. Commodity price swings, interest rate fluctuations, confidence levels, stock market crashes, and black swan events such as the Covid19 pandemic may contribute to economic uncertainty (Pettinger, 2020). While Vo (2019) reported that increased income inequality harms economic development, meaning it leads to a decline in economic growth, particularly in middle- 
income countries. The implications of this situation could lower the country's productivity and even cause a slowdown in national development, resulting in job losses.

Unemployment is traditionally thought to be either a business failure or a market feature (Tcherneva, 2017). The former is caused by market flaws like pay rigidities, quest frictions, and matching issues. The latter is a macroeconomic situation that is assumed to emerge spontaneously from market forces, such as the non-accelerating inflation rate of unemployment. Globalization and the reduction of manufacturing jobs were mostly cited as contributing factors to the problem's unavoidable consequence. The general opinion is that some degree of unemployment will always exist, probably growing. Substantial economic hardship, especially unemployment and underemployment, has resulted in a slew of socioeconomic and health issues, all of which have contributed to the rise in mortality. However, the relationship between poverty and dying is even stronger (Case, 2015). Based on the above scenario, therefore, the researchers articulated the following hypothesis:

\section{$\mathrm{H}_{3}$ : There is a significant influence of economic instability on the unemployment crisis.}

\section{RESEARCH FRAMEWORK}

A research framework has been established between the independent variables and the dependent variable, illustrated in Fig. 1.

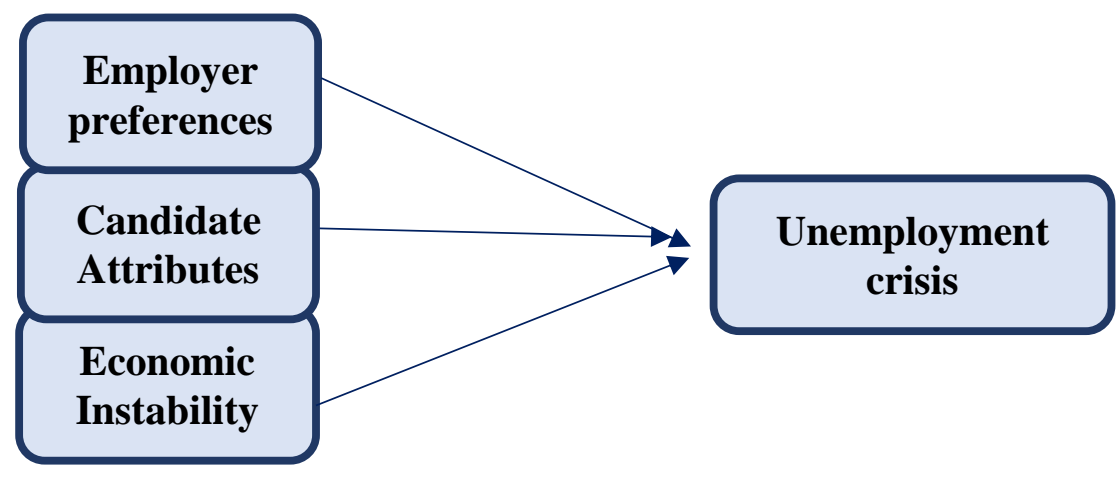

Figure 1. Research framework

\section{Research Design}

\section{METHODOLOGY}

Research design is a form of the procedure of information collection and analysis of the research. This study focused on the three key variables central to the unemployment crisis: employer's preferences, candidate's attributes, and economic instability among fresh graduates in Selangor. This study used the deductive method, starting with the hypothesis and ends result would be confirmed or rejected. A quantitative research approach was used in this study, which is a descriptive and cross-sectional study. The descriptive design focuses on collecting the information to answer the unemployment crisis through surveys in Selangor state. The survey methods aim to get answers from the respondents, and the fresh graduates were distributed among them, by online Google form including the open-ended question. The quantitative is collected according to the established appropriate research methodology and questionnaires and uses research approaches such as structured observation, online surveys, and questionnaires to get results from respondents. The information is gathered by performing statistical, mathematical, or computational techniques. This approach is the statistical methodology required to analyse the numerical data with the help 
of applications of SPSS. The positivistic researchers' conviction is that the social world comprises concrete and unchangeable reality which can be evaluated impartially. The positivist model was predominant in friendly and instructive exploration by giving the significance of utilizing government sanctioned tests and precise perception, try review information, and measurable examination (Rahman, 2017). Therefore, the quantitative research method is quite influential.

\section{Data Collection}

The survey instrument aimed to identify the relationships between employers' preference, candidates' attributes, and economic instability and unemployment among graduates. The selection of the group of respondents was made through random sampling of fresh graduates. The questionnaires have been distributed to 130 respondents. All questionnaires were found to be usable for the analysis, obtaining a $100 \%$ of response rate. The questionnaire consists of six sections, where the first section A addressed respondent demographics, followed by questions Section B relating to the unemployment crisis, the third section, C, is a question about Employer's preference, for section D is about candidate's attributes and the fifth section E considered about economic instability, which made use of a Likert scale one to seven ranging from "strongly disagree" to "strongly agree." The respondents of this study were requested to indicate their level of perceptions on a 7-point Likert Scale, ranging from Strongly Disagree (1) to Strongly Agree (7). Finstad (2010) contended that 7-point scale Likert items are more suitable for electronically transmitted and otherwise unsupervised usability questionnaires since they offer a more precise indicator of a participant's accurate evaluation. The set of questionnaires is formulated based on the chosen variables from the previous studies: unemployment crisis (Longe, 2017), employer's preferences (Mncayi, 2016), candidate's attributes (Hossain, 2018), and economic instability (Hwang, 2017).

\section{DATA ANALYSIS AND FINDINGS}

Based on Table 1, the males (47.7\%) are slightly less than the female respondents $(52.3 \%)$. The highest age group is from 24 to 28 (years old) (45.4\%), showing those who have just graduated, followed by the group category of those from the age of 19 to 23 (years old) (33.1\%). For the race group, the Indian (48.5\%) led the way and followed by the Malay (23.8\%) and the Chinese $(20.8 \%)$. The majority of the respondents' qualification is from the bachelor's degree group $(60.0 \%)$, followed by a diploma or STPM holders $(20.0 \%)$. Only $(17.7 \%)$ of the respondents come from master's degree groups. The results of the duration of the unemployed group of respondents show that (49.2\%) have been categorized as less than 6-month unemployed group, (37.7\%) less than the 18-month unemployed group, and (10.8\%) less than the 12-month are an unemployed group - the type of institution group of respondents shows. Almost two-thirds of the respondents $(63.8 \%)$ are from a private university. The rest (36.2\%) are from a public university. Most of the respondents are from $(53.8 \%)$ of the business and accountancy field. It is followed by (17.7\%) from arts, and social, (10.8\%) from the education field, and (9.2\%) from other groups (8.5\%) are from the technical. Therefore, based on the descriptive analysis, all the respondents seem appropriate to participate in this study. 
Table 1. Demographic Profile

\begin{tabular}{|c|c|c|}
\hline Characteristics & Frequency & $\%$ \\
\hline Gender & 62 & 47.7 \\
\hline Male & 68 & 52.3 \\
\hline \multicolumn{3}{|l|}{ Female } \\
\hline \multicolumn{3}{|l|}{ Age } \\
\hline $19-23$ & 43 & 33.1 \\
\hline $24-28$ & 59 & 45.4 \\
\hline $29-33$ & 26 & 20.0 \\
\hline 34-38 & 2 & 1.5 \\
\hline \multicolumn{3}{|l|}{ Race } \\
\hline Malay & 31 & 23.8 \\
\hline Chinese & 27 & 20.8 \\
\hline India & 63 & 48.5 \\
\hline Others & 9 & 6.9 \\
\hline \multicolumn{3}{|l|}{ Academic Qualification } \\
\hline Master Degree & 23 & 17.7 \\
\hline Bachelor Degree & 78 & 60.0 \\
\hline Diploma / STPM & 26 & 20.0 \\
\hline Others & 3 & 2.3 \\
\hline \multicolumn{3}{|l|}{ Duration of unemployment } \\
\hline Less than months & 64 & 49.2 \\
\hline Less than 12 months & 14 & 10.8 \\
\hline Less than 18 months & 49 & 37.7 \\
\hline Less than 24 months & 3 & 2.3 \\
\hline \multicolumn{3}{|l|}{ Type of Institution } \\
\hline Public (IPTA) & 47 & 36.2 \\
\hline Private (IPTS) & 83 & 63.8 \\
\hline \multicolumn{3}{|l|}{ Field of Studies } \\
\hline Technical & 11 & 8.5 \\
\hline Education & 14 & 10.8 \\
\hline Arts \& Social Science & 23 & 17.7 \\
\hline Business and accountancy & 70 & 53.8 \\
\hline Others & 12 & 9.2 \\
\hline
\end{tabular}

\section{Reliability Test}

Table 2 represents the variables of reliability test conducted throughout Cronbach's Alpha test to test data consistency. The scale of Cronbach's Alpha test should be more than 0.7 as it was standardized initially. The Cronbach's Alpha for the unemployment crisis is $0.885,0.902$ for employer's preferences, 0.891 for candidate's attributes, and 0.815 for economic instability, confirming that all the variables are reliable. 
Table 2. Reliability Test

\begin{tabular}{|l|c|c|}
\hline \multicolumn{1}{|c|}{ Variables } & Cronbach's Alpha & Item \\
\hline Unemployment crisis & .885 & 5 \\
\hline Employer preference & .902 & 5 \\
\hline Candidate attributes & .891 & 5 \\
\hline Economic instability & .815 & 5 \\
\hline
\end{tabular}

\section{Regression Analysis}

This research presents that all variables must have a normal distribution. The absolute value of skewness of $-/+2$ and kurtosis values of $-/+7$ is used to determine normality, and these values are considered adequate (Kline 2005). The skewness and kurtosis values in Table 3 are within the threshold values, indicating that the data is normal.

Table 3. Normality Test

\begin{tabular}{|l|c|c|c|c|}
\hline \multicolumn{1}{|c|}{ Variable } & Mean & STD & Skewness & Kurtosis \\
\hline Unemployment crisis & 5.2708 & 1.38516 & -1.441 & 1.701 \\
\hline Employer's preference & 5.0062 & 1.50677 & -.914 & .062 \\
\hline Candidate attribute & 4.6938 & 1.63360 & -.741 & .346 \\
\hline Economic instability & 4.9800 & 1.28337 & -1.193 & .832 \\
\hline
\end{tabular}

Multicollinearity frequently occurs when there are robust multiple correlations between some or all of the variables. This study employs the Variance Inflation Factors (VIF) analysis to determine the presence of multicollinearity. Multicollinearity can be determined using the tolerance calculation $(1=\mathrm{R} 2)$, which requires values greater than 0.1 , and the Variance Inflation Factor (1/Tolerance) requires values less than 10. If the tolerance value is less than 0.1 and the VIF is greater than 10, there is a significant issue with multicollinearity, and additional actions must be taken. As shown in Table 4, Employer's preference $(\mathrm{T}=0.519, \mathrm{VIF}=1.927)$, candidate's attributes $(\mathrm{T}=0.670, \mathrm{VIF}=1.492)$, and economic instability $(\mathrm{T}=0.510, \mathrm{VIF}=1.962)$ all exceeded the cut-off values, indicating that the values met the cut-off and confirming that there is no issue with multicollinearity

Table 4. Multi-Collinearity Analysis

\begin{tabular}{|l|c|c|}
\hline \multicolumn{1}{|c|}{ Variables } & Tolerance & VIF \\
\hline Employer's preference & .519 & 1.927 \\
\hline Candidate attributes & .670 & 1.492 \\
\hline Economic instability & .510 & 1.962 \\
\hline
\end{tabular}

Next, a linear correlation was tested using the bivariate correlation. It ensures that the correlation between the variables is a linear correlation to proceed with further regression analysis. The finding, as shown in Table 5, indicates that all the variables tested are linear correlations. The results indicated there were moderate and statistically significant relationships between employer's preference $(r=614, p<0.01)$, candidate's attribute $(r=.633, p<0.01)$, economic instability $(r=.626$, $\mathrm{p}<0.01$ ), and unemployment crisis. 
Table 5. Bivariate Correlation

\begin{tabular}{|l|l|l|l|}
\hline & Employer's preference & Candidate attribute & Economic instability \\
\hline Unemployment crisis & $.614^{* *}$ & $.633^{* *}$ & $.626^{* *}$ \\
\hline Employer's preference & 1 & $.518^{* *}$ & $.666^{* *}$ \\
\hline Candidate attribute & $.518^{* *}$ & 1 & $.530^{* *}$ \\
\hline Economic instability & $.666^{* *}$ & $.530^{* *}$ & 1 \\
\hline
\end{tabular}

**. Correlation is significant at the 0.01 level (2-tailed).

In the final analysis, a standard multiple regression was performed between employer's preference, candidate's attribute, economic instability, and unemployment instability as the dependent variable. Table 6 explained the regression analysis of correlations between the variables. The standardized Regression $(\beta), \mathrm{R} 2$, and adjusted R2 were discussed. According to the results, the overall model is supported significantly with a high $\mathrm{F}$ value of $51.312(\mathrm{p}<.000)$. Adjusted R square (.539) indicates that the three variables substantially explain the variance in the unemployment instability. Among the three relationships tested in the model, the standardized coefficient indicates statistically significant between Employer's preference and unemployment crisis $(\beta=0.287, p>.000)$. Also, there was a statistically significant between the candidate's attribute $(\beta=0.104, p<.000)$, economic instability $(\beta=0.321, p<.000)$, and the unemployment crisis. Considering the three hypotheses discussed earlier, all the hypotheses H1, H2, and H3 are supported.

The finding of this study is in line with some previous studies like Belwal et al. (2017), who examined employer' preference for having knowledgeable, skillful, and well-mannered individuals. Rajoo (2016) agreed too that Employer prefers those who are self-confident. Mncayi's (2016) study stated that employers are more likely to recruit people with experience, which leads to unemployment. Fresh graduates with little work experience are left behind, resulting in unemployment.

For the candidate's attribute, this study is concurrent with Suppramaniam et al.'s (2019) study that pointed out that some candidates are choosy in getting employed. Jayasingam et al. (2018) also approved that candidates always look for a higher position and better pay. For the third finding on the economic instability, this study is in line with Pettinger (2020), who asserted that when the economy's normal operations have been disrupted, and there is economic instability.

Table 6. Coefficients in the Regression Analysis

\begin{tabular}{|l|c|c|c|c|c|}
\hline \multicolumn{1}{|c|}{ Model } & \multicolumn{2}{|c|}{$\begin{array}{c}\text { Unstandardized } \\
\text { Coefficients }\end{array}$} & $\begin{array}{c}\text { Standardized } \\
\text { Coefficients }\end{array}$ & t & Sig. \\
\hline & $\mathrm{B}$ & Beta & Beta & & \\
\hline Constant & .841 & .217 & & 3.869 & .000 \\
\hline $\begin{array}{l}\text { Employer's } \\
\text { preference }\end{array}$ & .307 & .056 & .287 & 5.458 & .000 \\
\hline Candidate attribute & .117 & .050 & .104 & 2.343 & .020 \\
\hline $\begin{array}{l}\text { Economic } \\
\text { instability }\end{array}$ & .339 & .056 & .321 & 6.037 & .000 \\
\hline $\mathrm{R}$ & & & $.742^{\mathrm{a}}$ & & \\
\hline $\mathrm{R}^{2}$ & & & .550 & & \\
\hline
\end{tabular}




\begin{tabular}{|l|l|l|l|l|l|}
\hline Adjusted R & & & .539 & & \\
\hline $\mathrm{F}$ & & & 51.312 & & \\
\hline
\end{tabular}

a. Predictors: (Constant), Employer's preference, Candidate attribute, Economic instability

\author{
b. Dependent Variable: Unemployment Crisis
}

\title{
DISCUSSION AND CONCLUSIONS
}

The objective of this study is to determine the factors influencing the unemployment crisis. This study revealed that economic instability is the most influential factor in the unemployment crisis, followed by the employer's preference and the candidate's attribute. Naturally, when economic instability happened, it leads to lower investment, lower spending, lower growth, and higher unemployment. The way countries handle their rising unemployment rates would affect the wellbeing and financial stability of millions of people and the economy's long-term viability. The economic instability leads to unemployment crises as most companies want to avoid more financial problems. These developments in international relations can cause fear, anxiety, and panic, resulting in a lack of economic stability because capital is a cowardly creature by nature. Secondly, the employer's preference factor has also been a determinant for the unemployment crisis. No doubt, the employer prefers the experienced to fresh graduates. The candidature should work extra hard to show his talent and capability despite his less experience to be hired. The fresh graduates should improve themselves in terms of their behaviour, computer skills, and language competency to be more competent as a team player in any organisation. As the results also show that the candidate's attribute factor also influenced unemployment. The findings suggest various policy implications, including reducing unemployment in the Malaysian economy, which necessitates an increase in public and private spending to stimulate economic growth and absorb a steady rise in labour supply and successful commercial policies. It will support exports and redirect imports, and a situation that strengthens the linkages between trade and economic growth, and thus unemployability. The academic curriculum designers from the Ministry of Higher Education probably need to emphasise on the soft and hard skills expected by the employers. This study is beneficial to policymakers in Malaysia who are attempting to control unemployment. The government should expand the number of technical and vocational institutes because these institutions will help to reduce unemployment.

\section{Limitation of the Research}

Like any other research, this study has its limitation. The respondents are only from the state of Selangor and the graduates are only those who have no jobs at the most 24 months after the graduation. The findings could have been different, if the respondents are from other states in Malaysia, or other part in globe. Having a longer period of unemployment may reveal different discovery.

\section{Recommendation for the Future Research}

The study suggests future research to use a larger sample size with more information about the unemployment crisis. Future researchers can explore the different independent variables of the unemployment crisis, such as knowledge of the Internet of Things, communication skills, spiritual intelligence, creativity, looks, and talent. The future researcher could also study the impacts of unemployment on graduates' economy, social, and psychology. He/ she could also investigate the causal effect of regulation or government policy on unemployment. These exciting studies can 
also precede the same research but with new contexts, such as unemployed people who resigned and were retrenched recently.

\section{ACKNOWLEDGMENT}

We would like to thank the Selangor State Government for funding this paper under grant SEMESTA-MBI 2020 (I/SEM-MBI/SS/2020/05).

\section{REFERENCES}

Amen, U. (2014). Employer's expectations versus performance of fresh graduates. Business schools. Market Forces, 9(2).

Atta ur Rahman, A. K. (2019). Factors affecting duration of unemployment among young graduates. Global Social Sciences Review, 7. http://dx.doi.org/10.31703/gssr.2019(IVII).04

Belwal, R. P. (2017). Graduate attributes and employability skills. International Journal of Educational Management.

Bernama. (8 February, 2021). Unemployment rate at 4.5 pct in 2020, highest since 1993. Retrieved from https://www.nst.com.my/news/nation/2021/02/664122/unemploymentrate-45-pct-2020-highest-1993

Case, A. a. (2015). Rising morbidity and mortality in midlife among white non-Hispanic Americans in the 21st century." Proceedings of the National Academy of Sciences of the United States of America, 112(49), 15078-83.

Consultant, E. (28 April, 2021). 116,000 Malaysian fresh graduates without a job in 2020 Choose a course with job demand. Eduspiral Consultant Services. Retrieved from https://eduspiral.com/2020/10/03/116000-malaysian-fresh-graduate-without-a-job-in2020/

DoSM), D. o. (2021). Retrieved from https://www.dosm.gov.my/v1/index.php

Finstad, K. (May, 2010). Response Interpolation and Scale Sensitivity: Evidence Against 5-Point Scales. Retrieved from Journal of Usability Studies, 5(3), 104-110. Retrieved from https://uxpajournal.org/wp-content/uploads/sites/8/pdf/JUS_Finstad_May_2010.pdf

Hossain. MI, K. S. (2018). Factors influencing unemployment among fresh graduates: a case study in Klang Valley, Malaysia. International Journal of Academic Research in Business and Social Sciences, 14. http://dx.doi.org/10.6007/IJARBSS/v8-i9/4859

Hwang, Y. (2017). What is the cause of graduates' unemployment? Journal of Educational Issues, 10. http://dx.doi.org/10.5296/jei.v3i2.11378

Jayasingam, S. F. (2018). 'I am competent so I can be choosy': choosiness and its implication on graduate employability. Studies in Higher Education, 43(7), 1119-1134. 
Kline, R. B. (2016). Principles and practices of structural equation modelling. In T. D. Little (Ed.),. New York: The Guilford Press.: Methodology in the social sciences (Fourth).

Longe, O. (2017). Graduate unemployment in Nigeria: causes, consequences and remediable approaches. American International Journal of Contemporary Research, 11.

Mncayi. (2016). An analysis of the perceptions of graduate unemployment among graduates from a South African university. International Journal of Social Sciences and Humanity Studies, 17. Retrieved from https://www.researchgate.net/publication/321242794

Mohamad, R. b. (13 September, 2020). Department of Statistics Malaysia Official Website. Retrieved from https://www.dosm.gov.my/v1/index.php/index.php?r=column/cthemeByCat\&cat=476\& bul_id=cDJkZjM5b2hjdjJZMDlvNDlueU54Zz09\&menu_id=Tm8zcnRjdVR

Morozova, M. A. (2017). THE UNEMPLOYMENT RATE. Retrieved from https://dspace.nau.edu.ua/bitstream/NAU/27865/1/Morozova\%20M.pdf

Mulders, J. O. (2019). Employers' age-related norms, stereotypes and ageist preferences in employment.

O'Halloran, D. F. (2018). An occupational perspective on three solutions to unemployment. Journal of Occupational Science, 25(3), 297-308: https://doi.org/10.1080/14427591.2018.1474128

O'Higgins, N. (2016). Youth unemployment. In Routledge Handbook of Youth and Young Adulthood (pp. 157-171). Routledge.

Pettinger, T. (2020). Causes of economic instability. Retrieved from https://www.economicshelp.org/blog/43/economics/causes-of-economic-instability/

Pheko, M. M. (2017). Addressing employability challenges: A framework for improving the employability of graduates in Botswana. International Journal of Adolescence and Youth, 22(4), 455-469: https://doi.org/10.1080/02673843.2016.1234401

Rahman, M. S. (2017). The Advantages and Disadvantages of Using Qualitative and Quantitative Approaches and Methods in Language "Testing and Assessment" Research: A Literature Review. Journal of Education and Learning, 6(1), 102. .

Rajoo, C. M. (2016). Unemployment among graduates in Malaysia. International Journal of Economics, Commerce and Management, 8. Retrieved from http://ijecm.co.uk

Seng, L. C. (2018). Malaysia public universities' graduate employability policies: An analysis of first degree graduates unemployment and underemployment issues. International Journal of Social Science and Humanities Research, 6(4), 480-489: https://doi.org/10.5281/zenodo.2589702 
Suppramaniam, S. S. (2019). An employability assessment of fresh business graduates in Kuala Lumpur from the perspective of employers. International Journal of Recent Technology and Engineering, 7(5), 307-317.

Tcherneva, P. R. (2017). Unemployment: The silent epidemic. Levy Economics Institute. Working Papers Series, (895).

Tengku Kamarul Bahrim, T. A. (2019). High rate of unemployment among graduates in Malaysia. E-Journal of Media \& Society, 3, 1-15.

Thern, E. d. (n.d.). (2017). Long-term effects of youth unemployment on mental health: does an economic crisis make a difference? J Epidemiol Community Health, 71(4), 344-349.

Venus Khim-Sen Liew, R. A. (2018). Macroeconomic instability index and Malaysia economic. International Business Research, 7. https://doi.org/10.5539/ibr.v11n3p179

Verd, J. M. (2019). Youth unemployment and employment trajectories in Spain during the Great Recession: what are the determinants?. Journal for Labour Market Research, 53(1), 1-20.

Verhaest, D. B. (2018). Do employers prefer overqualified graduates? A field experiment. Industrial Relations. A Journal of Economy and Society, 57.

Vo, D. H. (2019). What factors affect income inequality and economic growth in middle-income countries?Journal of Risk and Financial Management, 12(1), 1-12. https://doi.org/10.3390/jrfm12010040

\section{Copyrights}

Copyright for this article is retained by the author(s), with first publication rights granted to the journal. This is an open-access article distributed under the terms and conditions of the Creative Commons Attribution license (https://creativecommons.org/licenses/by/4.0). 